\title{
Comparison of the Functional and Pasting Characteristics of Millet (Pennisetum Glaucum), African Yam Bean (Sphenostylis Stenocarpa Hoechst Ex. A. Rich) and Tiger Nut (Cyperus Esculentus) Flour Blends for Complementary Food Production
}

\author{
Obomeghei $\mathrm{AA}^{1 *}$, Olapade $\mathrm{AA}^{2}$, Ebabhamiegbebho $\mathrm{PA}^{3}$ \\ ${ }^{1,2}$ Department of Food Technology, University of Ibadan, Ibadan, Oyo State, Nigeria
${ }^{3}$ Food Science and Nutrition Unit, Department of Animal Science, University of Benin, Benin-City, Edo State, Nigeria
}

\section{Article History \\ Received: 02.02.2021 \\ Accepted: 18.03 .2021 \\ Published: 10.04.2021}

Journal homepage:

https://www.easpublisher.com

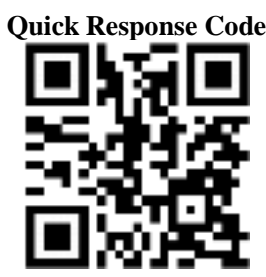

Abstract: Challenges such as protein-energy malnutrition are usually encountered during the period of complementary feeding and this can conveniently be attributed to over consumption of cereal based complementary foods in developing worlds, thus the need for incorporation of cheap protein food sources such as legumes in order to increase the protein content of the cereal based weaning foods. Millet, African yam bean and tiger nuts are among the underutilized, cheap and readily available crops found in African and many developing countries of the World. The successful use of plant protein sources as food ingredients depend to a large extent on their contribution to the overall beneficial qualities they impact to the manufactured food and this depend to a large extent on their functional and pasting properties. This research is aimed at investigating the functional and pasting properties of ten formulated flour blends from these crops in order to establish an appropriate formula for an affordable complementary food production. Functional and pasting properties of the flour blends were determined using standard procedures. The results obtained showed that bulk density ranged from 0.62 to $0.77 \mathrm{~g} / \mathrm{ml}$; water absorption capacity between 151 and $175 \%$; swelling power between 4.21 and $5.60 \%$. The peak viscosity ranged from 100 to $117 \mathrm{RVU}$; breakdown from 9.83 to $14.17 \mathrm{RVU}$; final viscosity between 142 and171.17 RVU; setback from 31.50 to $67.42 \mathrm{RVU}$; pasting temperature from 84.83 to $88.10^{\circ} \mathrm{C}$. This study revealed that all samples will make firm gels and good products.

Keywords: Functional, pasting, characteristics, millet, African-yam-bean, tiger-nut, complementary, food, blends.

Copyright (9) 2021 The Author(s): This is an open-access article distributed under the terms of the Creative Commons Attribution 4.0 International License (CC BY-NC 4.0) which permits unrestricted use, distribution, and reproduction in any medium for non-commercial use provided the original author and source are credited.

\section{INTRODUCTION}

Malnutrition in children is a major nutritional challenge in developing countries which leads to morbidity and mortality, retardation in physical growth and mental development, working capacity and increased risk of adult disease [1]. Malnutrition leads to unwelcome developments such as death, extended periods of hospitalization, poor quality of life and physical frailty. Malnutrition often begins at conception, and infant malnutrition is closely related with poverty, low levels of education, and lack of access to health facilities [2]. Therefore, early detection of malnutrition and subsequent nutritional intervention can significantly benefit the vulnerable population in addition to economic benefits like reducing the cost of medical care [3]. The growth of infants and children in the first two years of life is very rapid. And only breast feeding will not be enough for the infants nutritional needs [4]. Complementary feeding is needed for both nutritional and developmental reasons, and is an important stage in the change from only milk feeding to family foods. Complementary feeding is described as the process starting from when breast milk alone is no longer enough to meet the nutritional requirement of infants as such other foods and liquids are required along with breast milk [5]. In developing countries like India and Nigeria complementary foods are mainly based on cereals like maize, sorghum, or millet and tubers such as sweet potato and cocoyam. Infants and children are usually fed these staples in the form of pap. Challenges such as protein-energy malnutrition are usually encountered during the period of complementary feeding and this can be attributed to over consumption of cereal based pap, thus the need for incorporation of legumes in order to increase the protein content of the cereal based complementary foods. 
Cereals and legumes constitute the majority of sources of nutrients for traditional weaning foods in the developing nations. Cereal such as pearl millet has been grown in Africa and the Indian subcontinent since prehistoric times [6]. It is widely grown in the northeastern part of Nigeria, especially in Borno and Yobe states. Pearl millet is a staple food in Africa and many other developing countries where it is used to make flour, bread, porridge and several local beverages. In West Africa pearl millet is mainly produced for its grain which is used for human consumption, but the crop is also of good economic importance in livestock feeds, building materials and fuel. Davis A.J et al. [7] reported that the protein content of pearl millet is greater than that of corn and noted that broiler chicken diets with $50 \%$ pearl millet performed better than cornsoybean diets. Pearl millet has been used staple as food crop for thousands of years in a variety of food products and continues to be used as a staple grain by approximately 90 million people in Africa and India [8]. It contains more nutrients than rice or wheat, but it is considered as a subsistence produce for developing countries [9]. The crop contains higher amount of gross energy than corn, higher concentration of amino acids and $27-32 \%$ more protein [8].

Tiger nut has been considered as a foodstuff since ancient times [10]. According to [10] there are records from the $13^{\text {th }}$ century that mentioned the consumption of a drink made from tiger nut in some Mediterranean areas especially the Valencia region (Southeast Spain). Recently, tiger nuts are also being grown in West Africa where they are mainly used as uncooked side dish and local beverages. Tiger nuts are rich in starch, oil, minerals, and vitamins; especially Vitamins $\mathrm{C}$ and $\mathrm{E}$. The starch and oil constitute the major macronutrients in the tiger nut tuber. The high starch content of tiger nut provides unique functional properties [11]. The tiger nut oil contains high monounsaturated fatty acids that are similar to those of olive, avocado and hazelnut oils [12]. The dried tiger nut has protein contents range of between 7.15 to $9.70 \%$, carbohydrate between 41.22 and $46.99 \%$, lipid between 32.13 and $35.43 \%$, and energy content of between 343 and $511 \mathrm{Kcal} / 100 \mathrm{~g}$ [13]. Tiger nuts are very popular in West Africa where they are eaten as snacks. They have various uses, such as horchata, a nonalcoholic beverage of milky appearance derived from the fresh tubers mixed with sugar and water, and commonly consumed in Spain [14]. "Kunnu" is a nonalcoholic beverage prepared mainly from cereals such as millet or sorghum with spices (like dandelion, alligator pepper, ginger, licorice) and sugar. To make up for the poor nutritional value of kunnu made from cereals, tiger nut was found to be a good substitute for cereal grains. And it is then known as "kunnu aya".

African yam bean belongs to the family Fabaceae characterized by it fruit (legume) and stipulated leaves. Three species of Sphenostylis are important food sources in Africa, including the underexploited African yam bean which can be consumed as dry cooked seeds or tuber. The African yam bean is grown in countries of West Africa such as Cameroon, Coe d'Ivoire, Ghana, Nigeria, and Togo [15]. African yam bean (Sphenostylis stenocarpa) is among the underutilized food legume crop found in the tropics; it is not as popular as other major food legumes [16]. It is a typical African plant cultivated in most parts of the hot and humid tropical regions and more specifically in southern parts of Nigeria [17]. The protein content of African yam bean seeds ranges between 21 and $29 \%$ and for the tubers the protein is about 2 to 3 times the amount found in potatoes [18] but higher than those in yam and cassava [19]. Moreover, the amino acid values in the seeds are higher than those in pigeon pea, cowpea, and bambara groundnut [18]. African yam bean is rich in minerals such as potassium, phosphorous, magnesium, calcium, iron and zinc but low in sodium and copper [20].

Most cereals are deficient in essential amino acids such as lysine and tryptophan [21]. And legumes are rich in lysine and tryptophan but deficient in sulphur containing amino acids, methionine and cystine. Combining cereal such as millet with African yam bean and tiger nut will promote the quality of traditional complementary foods.

The use of low cost and easily available and underutilized raw materials with good functional and pasting properties in the preparation of complementary foods is on the increase. The functionality and pasting properties of starch plays important roles in the control of moisture, texture, viscosity, consistency, mouth-feel and shelf-life of manufactured food products [22]. This study aims at formulating and evaluation of the functional and pasting characteristics of food blends from pearl millet, African yam bean and tiger nut for use in complementary foods production

\section{Materials ANd MethodS Materials}

African yam beans were obtained from Genetic Resources Centre, International Institute for Tropical Agriculture (IITA), Ibadan. While pearl millets and tiger nuts were purchased from a local dealer at Bodija market, Ibadan. The chemicals used for various analyses were purchased from Pyrex representative, Ibadan, Nigeria.

\section{Methods \\ Production of millet flour}

Three kilogram $(3 \mathrm{~kg}$ ) pearl millet grains were sorted to remove stones, dirt and other extraneous materials. The clean grains were washed and steeped in water $\left(30 \pm 2^{0} \mathrm{C}\right.$ for $48 \mathrm{hrs}$ for fermentation to take place. Fermented grains were dried in a cabinet drier at $80^{\circ} \mathrm{C}$ for $3 \mathrm{hrs}$ and dry milled in an attrition mill (Franky DMWP 200 Electric Cereal mill) and were sieved using 
$210 \mu \mathrm{m}$ sieve to obtain the flour. The flours were packaged in high density polyethylene $(0.08 \mathrm{~mm}$ thick) and stored in a deep freezer $\left(-10^{\circ} \mathrm{C}\right)$

\section{Production of tiger nut flour}

The method described by [13] was used to prepare tiger nut flour. Dry tiger nut were sorted to remove extraneous materials and washed with portable water. The clean nuts were dried at $105^{\circ} \mathrm{C}$ for $3 \mathrm{hrs}$. The dried nuts were milled, sieved and packaged in high density polyethylene and stored in deep freezer.

\section{Production of African yam beans flour}

The method of [23] was used for the preparation of African yam bean flour. The seeds were handpicked, carefully sorted and winnowed to remove immature and unwholesome seeds and other extraneous materials. The cleaned seeds were steeped in warm water $\left(45^{\circ} \mathrm{C} ; 10 \mathrm{hrs}\right)$ in a thermostatic water bath. The seeds were manually dehulled and washed and then decanted to remove the seed coats. The seeds were then dried in a cabinet drier $\left(60^{\circ} \mathrm{C} ; 8 \mathrm{hrs}\right)$ and milled in an attrition mill through a $210 \mu \mathrm{m}$ sieve and packaged in a high density polyethylene and stored in a deep freezer.

\section{Formulation of complementary food blends}

Ten (10) complementary food blends were formulated in the specified ratio to make $100 \%$ as shown in Table 1.0
Table-1.0 Formulation of complementary food blends (\%)

\begin{tabular}{|l|l|l|l|l|}
\hline S/N & Sample code & PMF & AYBF & TNF \\
\hline 1 & ITS & 70 & 20 & 10 \\
\hline 2 & OTO & 75 & 10 & 15 \\
\hline 3 & BSA & 80 & 10 & 10 \\
\hline 4 & OAB & 70 & 15 & 15 \\
\hline 5 & OAK & 71.67 & 11.67 & 16.67 \\
\hline 6 & BUI & 70 & 10 & 20 \\
\hline 7 & CUO & 73.33 & 13.33 & 13.33 \\
\hline 8 & BEL & 76.67 & 11.67 & 11.67 \\
\hline 9 & LAC & 71.67 & 16.67 & 11.67 \\
\hline 10 & OPE & 75 & 15 & 10 \\
\hline
\end{tabular}

$\mathrm{PMF}=$ Pearl millet flour, AYBF = African yam bean flour, $\mathrm{TNF}=$ Tiger nut flour

\section{Determination of bulk density (loose/ tapped)}

The method described by [24] was used to determine the bulk density of the samples. A $10 \mathrm{ml}$ graduated measuring cylinder was weighed and filled with a known weight of of sample, and the bottom of the cylinder was gently tapped on the laboratory bench several times until there is no further diminution of the sample level after filling to the $10 \mathrm{ml}$ mark. The packed volume was recorded and the bulk density was calculated as the ratio of the sample weight to the volume occupied by the sample after tapping.

Tapped bulk density $\left(\frac{g}{m l}\right)=\frac{\text { weight of sample }}{\text { volume of sample }}$

Loose bulk density $\left(\frac{g}{m l}\right)=\frac{\text { weight of loosely packed sample }}{\text { volume of sample }}$

\section{Determination of swelling power and solubility index}

The swelling capacity was determined as described by [25]. About $1 \mathrm{~g}$ of the sample was accurately weighed into $50 \mathrm{ml}$ centrifuge tube; $10 \mathrm{ml}$ of distilled water was added and mixed gently. The slurry was heated in a water bath at temperature of $100^{\circ} \mathrm{C}$ for
15 minutes. During heating, the slurry was stirred gently to prevent clumping of the flour. After 15 minutes, the tube containing the paste was centrifuged at $3000 \mathrm{rpm}$ for 15 minutes. The supernatant was decanted immediately. The weight of the sediment was taken and recorded.
Swelling power $\left(\frac{g}{g}\right)=\frac{\text { weight of wet sediment }}{\text { weight of sample-weight of soluble }}$
Solubility index $\left(\frac{g}{g}\right)=\frac{\text { weight remains after drying }}{\text { initial weight of sample }} \ldots \ldots$

\section{Determination of gelation concentration}

The method described by [24] was used to determine the gelation capacity. A sample suspension of $2 \%-20 \%(\mathrm{w} / \mathrm{v})$ in $5 \mathrm{ml}$ of distilled water was prepared in test tubes. The samples in the test tubes were heated for 1 hour in a boiling water bath followed by rapid cooling under running tap water. The test tubes were further cooled for 2 hours at $4^{0} \mathrm{C}$. The least gelation concentration was determined as the concentration when the sample from the inverted test tube did not fall or slip.

\section{Determination of water absorption capacity}

The water absorption capacity was determined as described by [24]. About $1 \mathrm{~g}$ of the sample was weighed into a clean $50 \mathrm{ml}$ centrifuge tube and mixed thoroughly with $10 \mathrm{ml}$ distilled water using a stirring rod for about 30 seconds. The sample was allowed to stand for 30 minutes at room temperature, after which it was centrifuged at $3500 \mathrm{rpm}$ for 30 minutes. After centrifugation, the volume of the free water (supernatant) was read directly from the graduated centrifuge tube. The absorbed water was converted to weight (in grams) by multiplying by the density of water $(1 \mathrm{~g} / \mathrm{ml})$. The water absorption capacity was 
expressed in grams of water absorbed per gram of sample.

Absorbed water $=$ total water - free water

\section{Determination of pasting properties}

Rapid Visco-Analyzer (RVA) of Newport Scientific, Warriewood, Australia was used to analyze the pasting properties of the flour blends upon heating and subsequent cooling. The RVA General Pasting Method (STD1) was applied. Total running time was 13 minutes and the viscosity values were recorded every 4 seconds by Thermocline Software as the temperature increased from $50^{\circ} \mathrm{C}$ to $95^{\circ} \mathrm{C}$ before cooling to $50^{\circ} \mathrm{C}$ again. Rotation speed was set to $960 \mathrm{rpm}$ for the first 10 seconds and to $160 \mathrm{rpm}$ until the end. About $3 \mathrm{~g}$ of the flour and $25.0 \mathrm{ml}$ of distilled water was placed in a canister and a paddle was inserted and shaken through the sample before the canister was inserted into the RVA.

\section{Statistical AnAlysis}

All determinations were done in triplicates and data obtained were statistically analyzed and subjected to one-way Analysis of Variance (ANOVA) using the Statistical Package for Social Sciences (SPSS) version 20, 2013. Means were compared and separated using Duncan's Multiple Range Test (DMRT) and LSD at $\mathrm{p} \leq 0.05$.

\section{RESUlTS AND DisCUSSIONS}

Functional properties of complementary food blends The results of the functional properties of millet, African yam bean and tiger nut complementary flour blends is presented in Table 2.0. There were significant differences $(p \leq 0.05)$ in both the loose and packed densities for all the complementary food blends. The loose bulk densities ranged from $0.50-0.54 \mathrm{~g} / \mathrm{ml}$ for samples OPE and BSA respectively. The packed bulk densities ranged from $0.62-0.77 \mathrm{~g} / \mathrm{ml}$ for samples OPE and BSA respectively. The values obtained in this study were within the range $(0.45-0.51 \mathrm{~g} / \mathrm{ml})$ for loose bulk density and $0.84-0.89 \mathrm{~g} / \mathrm{ml}$ for packed density reported by [26] for plantain and cowpea complementary food blends. The range $0.77-0.87 \mathrm{~g} / \mathrm{ml}$ for packed densities reported by [27] for orange fleshed sweet potato and Bambara groundnut flour blends is similar to the range obtained in this study. The range $0.62-0.70 \mathrm{~g} / \mathrm{ml}$ reported by [5] for sorghum, African yam bean and soybean complementary food blends are also within the range obtained in this experiment. The range $0.54-0.80 \mathrm{~g} / \mathrm{ml}$ was reported by [28] for defatted almond seed, yellow maize and quality maize flour blends. The value $0.65 \mathrm{~g} / \mathrm{ml}$ for orange fleshed sweet potato, cowpea and groundnut flour blends was reported by [29] while the value $0,61 \mathrm{~g} / \mathrm{ml}$ was reported by [30] for sorghum-mung bean-orange fleshed sweet potato flour blends. The values of the bulk densities obtained in this experiment imply that the sinkability and ability to disperse during mixing of sample BSA is higher than those of all other samples. The high densities of the flour blends obtained in this study indicate high dispersability of all the blends. It implies that all the blends will reconstitute to consistent mixture in mixing operations. The densities also signify that the blends are heavy and therefore less quantity of the flours can be packed in a specified volume. The densities of flours are very important in estimating packaging requirement and material handling operations.

The water absorption capacity (WAC) is an important property of flour in the development of ready to - eat - food cereal grains, as a high water absorption capacity may assure cohesiveness of products [31]. High water absorption capacity is generally an indication of the loose association of the starch polymer in the native granules. There are significant differences in the water absorption capacity of all the complementary food blends. The values of WAC obtained in this study ranged from $151 \%$ to $175 \%$. This range is similar to the range $150-180 \%$ reported by [26] for plantain and cowpea complementary food blends. The range is also in consonance with the range $168-179 \%$ reported by [30] for sorghum, mung beans and orange fleshed sweet potato weaning foods.

Table-2.0: Functional properties of complementary food blends of millet, African yam bean and tiger nut flours

\begin{tabular}{|l|l|l|l|l|l|l|}
\hline Sample & $\begin{array}{l}\text { Loose bulk } \\
\text { density } \\
(\mathbf{g} / \mathbf{m l})\end{array}$ & $\begin{array}{l}\text { Packed bulk } \\
\text { density } \\
(\mathbf{g} / \mathbf{m l})\end{array}$ & $\begin{array}{l}\text { WAC } \\
(\%)\end{array}$ & $\begin{array}{l}\text { Swelling } \\
\text { power } \\
(\mathbf{9 0} \mathbf{C})\end{array}$ & $\begin{array}{l}\text { Swelling } \\
\text { power } \\
\left(\mathbf{1 0 0} \mathbf{C}^{\mathbf{0}}\right)\end{array}$ & $\begin{array}{l}\text { Solubility } \\
(\%)\end{array}$ \\
\hline ITS & $0.51 \pm 0.02^{\text {cd }}$ & $0.73 \pm 0.01^{\mathrm{g}}$ & $161 \pm 0.00^{\mathrm{c}}$ & $5.10 \pm 0.28^{\mathrm{d}}$ & $5.11 \pm 0.01^{\mathrm{cd}}$ & $0.11 \pm 0.07^{\mathrm{a}}$ \\
\hline OTO & $0.51 \pm 0.01^{\mathrm{bc}}$ & $0.73 \pm 0.01^{\mathrm{g}}$ & $166 \pm 0.21^{\mathrm{b}}$ & $4.67 \pm 0.00^{\mathrm{d}}$ & $4.87 \pm 0.03^{\mathrm{f}}$ & $0.00 \pm 0.00^{\mathrm{b}}$ \\
\hline BSA & $0.54 \pm 0.00^{\mathrm{a}}$ & $0.77 \pm 0.02^{\mathrm{ab}}$ & $151 \pm 0.01^{\mathrm{c}}$ & $4.00 \pm 0.26^{\mathrm{a}}$ & $4.20 \pm 0.00^{\mathrm{h}}$ & $0.00 \pm 0.00^{\mathrm{b}}$ \\
\hline OAB & $0.52 \pm 0.00^{\mathrm{bc}}$ & $0.75 \pm 0.00^{\mathrm{d}}$ & $161 \pm 0.01^{\mathrm{c}}$ & $5.00 \pm 0.16^{\mathrm{d}}$ & $5.01 \pm 0.01^{\mathrm{c}}$ & $0.00 \pm 0.00^{\mathrm{b}}$ \\
\hline OAK & $0.51 \pm 0.00^{\text {cd }}$ & $0.71 \pm 0.00^{\mathrm{h}}$ & $165 \pm 0.00^{\mathrm{b}}$ & $4.40 \pm 0.07^{\mathrm{g}}$ & $4.57 \pm 0.04^{\mathrm{a}}$ & $0.00 \pm 0.00^{\mathrm{b}}$ \\
\hline BUI & $0.52 \pm 0.01^{\mathrm{a}}$ & $0.76 \pm 0.00^{\mathrm{bc}}$ & $152 \pm 0.00^{\mathrm{e}}$ & $4.91 \pm 0.09^{\mathrm{d}}$ & $4.93 \pm 0.04^{\mathrm{f}}$ & $0.00 \pm 0.00^{\mathrm{b}}$ \\
\hline CUO & $0.51 \pm 0.01^{\mathrm{cd}}$ & $0.71 \pm 0.00^{\mathrm{h}}$ & $175 \pm 0.00^{\mathrm{a}}$ & $4.18 \pm 0.16^{\mathrm{h}}$ & $4.21 \pm 0.01^{\mathrm{h}}$ & $0.00 \pm 0.00^{\mathrm{b}}$ \\
\hline BEL & $0.53 \pm 0.00^{\mathrm{a}}$ & $0.74 \pm 0.00^{\mathrm{e}}$ & $160 \pm 0.00^{\mathrm{cd}}$ & $5.60 \pm 0.00^{\mathrm{a}}$ & $5.60 \pm 0.00^{\mathrm{a}}$ & $0.11 \pm 0.01^{\mathrm{a}}$ \\
\hline LAC & $0.52 \pm 0.00^{\mathrm{b}}$ & $0.74 \pm 0.02^{\text {ef }}$ & $158 \pm 0.07^{\mathrm{d}}$ & $4.81 \pm 0.27^{\mathrm{a}}$ & $4.90 \pm 0.00^{\mathrm{f}}$ & $0.001 \pm 0.00^{\mathrm{b}}$ \\
\hline OPE & $0.50 \pm 0.01^{\mathrm{d}}$ & $0.62 \pm 0.00^{\mathrm{i}}$ & $165 \pm 0.00^{\mathrm{b}}$ & $5.20 \pm 0.03^{\mathrm{b}}$ & $5.30 \pm 0.07^{\mathrm{c}}$ & $0.10 \pm 0.00^{\mathrm{a}}$ \\
\hline
\end{tabular}

Values within a column with different superscripts are significantly different $(\mathrm{p} \leq 0.05)$ 
Bello, F.A; Edeke, J.E et al. [5] Reported a range $130-240 \%$ for sorghum, African yam beans and soybean complementary food blends. And a range of $150-350 \%$ was reported by [28] for defatted almond seed, yellow maize and quality protein maize flours. Water absorption capacity is reflective of protein-water interaction in food systems and is therefore influenced greatly by protein content [32]. The high water absorption capacity observed in the flour blends is indicative of the possession of large number of waterbinding sites due to the availability of hydrophilic and hydrophobic sites present in the starch molecules [33, 34]. Water absorption capacity is a desirable property of flour for food systems to improve yield and consistency and to give body to the food [35].

Swelling power is a measure of the hydration capacity of starches and it is used to provide evidence for associative binding forces within the starch granules [36]. According to [37] swelling power is an important property used to determine the amount of water that a food sample would absorbed in addition to the degree of swelling within a specified time interval. There were significant differences $(p \leq 0.05)$ in the swelling power at $100^{\circ} \mathrm{C}$ for all the samples. The swelling power obtained in this study ranged from 4.20 to 5.60 for samples BSA and BEL respectively. These values are slightly lower than the values $(4.64-7.13 \%)$ reported by [30] for weaning food blends made from sorghum, mung beans and orange fleshed sweet potato. The values of swelling powers obtained in this experiment were observed to be far higher than the range $2.50-3.10 \%$ reported by [28] for complementary food blends made from defatted almond seed, yellow maize and quality protein maize flours. Bello F.A et al. [5] reported a range $1.00-$ $1.10 \%$ for complementary food blends made from sorghum, African yam beans and soybean. The values of swelling power obtained in this study indicate that sample BEL with highest swelling power will form a thick viscous gruel than all other samples.

Solubility index is used to describe the extent of solubility of a flour sample and its potentials to gelatinize with much residual particles. It is an important property which is ultimately used to ascertain the consistency of food gruels [38]. The solubility index obtained in this experiment ranged between 0.00 and $11.0 \%$. There were significant differences $(\mathrm{p} \leq 0.05)$ in the solubility of all the samples. Samples ITS and BEL are not significantly different from each other but are significantly higher than all the other samples [27]. Obtained a range between 9.27 and $11.67 \%$ for orange fleshed sweet potato and Bambara groundnut flour blends while [30] reported a range between $12.00-$ $20.50 \%$ for weaning food blends made from sorghum, Mung bean and orange fleshed sweet potato.

\section{Pasting properties of complementary food blends}

The pasting properties are the most commonly assessed quality parameters which could be as a result of the fact that the methods are well established and have been proven to be reliable predictor of flour quality. Pasting properties are important as they are used in predicting the pasting behaviors and abilities of the flour samples [39]. The results of the pasting properties of complementary food blends are presented in Table 3.0. The peak viscosity obtained in this study ranged from 100.58 to $117.17 \mathrm{RVU}$. There were no significant differences $(\mathrm{p} \leq 0.05)$ between samples ITS, OTO, BSA, OAB, CUO, and LAC. But significant differences exist between these samples and samples OAK, BUI, and BEL. Sample LAC had the highest peak viscosity while sample BEL had the lowest value. The values of peak viscosity obtained in this study are far higher than the range $42.30-92.69$ RVU reported by [39] for wheat and walnut flour blends but are within the ranges $87-214$ RVU reported by [30] for weaning food blends made from sorghum, Mung beans and orange fleshed sweet potato flours [27]. Reported a range between 92.88 - 109.34 RVU for orange fleshed sweet potato and Bambara groundnut flour blends.

Flour performances in food systems depend on the cooking behavior of their starches, and it provides us with beneficial information in new food product development. High peak viscosity is an index of the relative suitability of the flour blends for products that requires high elasticity and strength [40]. Peak viscosity indicates the highest value of viscosity attained in a heating cycle by gelatinized starches and it is used to measure the ability of flours to form pastes.

The peak viscosity is also is indicative of the strength of pastes that are formed from gelatinization during processing in food applications. It provides an indication of the viscous load likely to be met during mixing operations [39].

The values of the trough viscosity ranged between 90.75 - 103.75 RVU. There were no significant differences $(\mathrm{p} \leq 0.05)$ among samples ITS, OTO, BSA, OAB, CUO, and LAC. But these were significantly higher than samples OAK, BUI, BEL and OPE. According to [41], trough viscosity is the point at which viscosity attained its minimum value during heating or cooling processes. It measures the ability of pastes to withstand breakdown during cooling.

The breakdown viscosity of cooked pastes indicates their stabilities to shearing during cooking [42]. Starches with low breakdown or low pasting stability have weak cross-linking within the granules of the flours. The breakdown viscosities ranged between 9.83 - 14.17 RVU with BSA having the highest and BUI having the lowest values. There were no significant differences $(\mathrm{p} \leq 0.05)$ among samples BSA, LAC and OPE. But these were observed to be significantly higher than samples ITS, OTO, OAB, OAK, BUI, CUO and BEL. The values of breakdown viscosities obtained in this experiment were observed to 
be far less than range 20.33 - 21.46 RVU reported by [27] for orange fleshed sweet potato and Bambara

groundnut flour blends.

Table-3.0: Pasting properties of complementary food blends made from millet, African yam bean and tiger nut

\begin{tabular}{|l|l|l|l|l|l|l|l|}
\hline Sample & $\begin{array}{l}\text { Peak viscosity } \\
\text { (RVU) }\end{array}$ & $\begin{array}{l}\text { Trough } \\
\text { (RVU) }\end{array}$ & $\begin{array}{l}\text { Breakdown } \\
\text { (RVU) }\end{array}$ & $\begin{array}{l}\text { Final } \\
\text { viscosity } \\
(\mathbf{R V U})\end{array}$ & $\begin{array}{l}\text { Set back } \\
(\text { RVU) }\end{array}$ & $\begin{array}{l}\text { Peak time } \\
\text { (minutes) }\end{array}$ & $\begin{array}{l}\text { Pasting } \\
\text { temperature } \\
(\mathbf{C} \text { C) }\end{array}$ \\
\hline ITS & $113.63 \pm 1.59^{\mathrm{abc}}$ & $101.21 \pm 2.33^{\mathrm{ab}}$ & $12.42 \pm 0.82^{\mathrm{b}}$ & $162.08 \pm 1.71^{\mathrm{b}}$ & $60.92 \pm 0.71^{\mathrm{ab}}$ & $5.33 \pm 0.09^{\mathrm{ab}}$ & $84.83 \pm 0.04^{\mathrm{bc}}$ \\
\hline OTO & $111.96 \pm 1.71^{\mathrm{bc}}$ & $99.88 \pm 2.00^{\mathrm{ab}}$ & $12.08 \pm 0.24^{\mathrm{b}}$ & $161.17 \pm 2.12^{\mathrm{b}}$ & $61.25 \pm 0.18^{\mathrm{ab}}$ & $5.33 \pm 0.00^{\mathrm{ab}}$ & $86.0 \pm 056^{\mathrm{bc}}$ \\
\hline BSA & $111.58 \pm 0.65^{\mathrm{ab}}$ & $101.54 \pm 0.53^{\mathrm{ab}}$ & $14.17 \pm 0.12^{\mathrm{a}}$ & $165.63 \pm 1.83^{\mathrm{ab}}$ & $64.08 \pm 1.30^{\mathrm{a}}$ & $5.33 \pm 0.00^{\mathrm{ab}}$ & $86.00 \pm 0.56^{\mathrm{bc}}$ \\
\hline OAB & $114.46 \pm 0.06^{\mathrm{abc}}$ & $98.17 \pm 0.24^{\mathrm{bc}}$ & $12.25 \pm 0.12^{\mathrm{b}}$ & $160.79 \pm 0.06^{\mathrm{b}}$ & $61.33 \pm 0.18^{\mathrm{ab}}$ & $5.28 \pm 0.02^{\mathrm{b}}$ & $88.10 \pm 2.83^{\mathrm{a}}$ \\
\hline OAK & $105.5 \pm 1.30^{\mathrm{d}}$ & $94.50 \pm 1.24^{\mathrm{cd}}$ & $10.96 \pm 0.06^{\mathrm{c}}$ & $149.33 \pm 1.18^{\mathrm{c}}$ & $54.75 \pm 0.06^{\mathrm{ab}}$ & $5.36 \pm 0.05^{\mathrm{ab}}$ & $88.05 \pm 0.00^{\mathrm{a}}$ \\
\hline BUI & $100.71 \pm 0.41^{\mathrm{c}}$ & $90.88 \pm 0.41^{\mathrm{d}}$ & $9.83 \pm 0.00^{\mathrm{d}}$ & $142.29 \pm 1.71^{\mathrm{c}}$ & $51.42 \pm 1.30^{\mathrm{ab}}$ & $5.33 \pm 0.00^{\mathrm{ab}}$ & $88.00 \pm 00^{\mathrm{a}}$ \\
\hline CUO & $111.58 \pm 1.06^{\mathrm{bc}}$ & $99.08 \pm 0.71^{\mathrm{b}}$ & $12.50 \pm 0.35^{\mathrm{b}}$ & $160.50 \pm 2.12^{\mathrm{b}}$ & $61.42 \pm 1.41^{\mathrm{ab}}$ & $5.40 \pm 0.00^{\mathrm{a}}$ & $87.67 \pm 0.60^{\mathrm{a}}$ \\
\hline BEL & $100.58 \pm 0.12^{\mathrm{c}}$ & $91.46 \pm 0.06^{\mathrm{d}}$ & $12.25 \pm 0.12^{\mathrm{b}}$ & $159.71 \pm 0.18^{\mathrm{b}}$ & $31.50 \pm 2.06^{\mathrm{b}}$ & $5.31 \pm 0.01^{\mathrm{ab}}$ & $84.88 \pm 0.23^{\mathrm{d}}$ \\
\hline LAC & $117.17 \pm 5.77^{\mathrm{a}}$ & $103.75 \pm 4.95^{\mathrm{a}}$ & $13.42 \pm 0.82^{\mathrm{a}}$ & $171.17 \pm 2.16^{\mathrm{a}}$ & $67.42 \pm 5.54^{\mathrm{a}}$ & $5.40 \pm 0.00^{\mathrm{a}}$ & $85.17 \pm 0.53^{\mathrm{cd}}$ \\
\hline OPE & $110.46 \pm 0.06^{\mathrm{c}}$ & $90.75 \pm 0.24^{\mathrm{d}}$ & $13.92 \pm 0.82^{\mathrm{a}}$ & $165.25 \pm 0.12^{\mathrm{ab}}$ & $62.46 \pm 0.41^{\mathrm{a}}$ & $5.27 \pm 0.02^{\mathrm{b}}$ & $86.26 \pm 0.22^{\mathrm{b}}$ \\
\hline
\end{tabular}

Values within a column with different superscripts are significantly different $(\mathrm{p} \leq 0.05)$

The final viscosities of the complementary food blends ranged between 142.29 to 171.17 RVU with sample BUI having the lowest and sample LAC having the highest values. There were no significant differences $(\leq 0.05)$ among sample LAC, OPE and BSA. But the values of these samples are significantly higher than samples ITS, OTO, OAB, CUO and BEL. Also significant differences does not exist among sample ITS, OTO, OAB, CUO, and BEL. The final viscosities obtained in this study are within the range $(50-175$ RVU) reported by [30] for sorghum, mung bean and orange fleshed sweet potato flour blends. The values of final viscosity documented in this study are higher than the range 102.71 - $132.00 \mathrm{RVU}$ reported by [27] for orange fleshed sweet potato and Bambara groundnut flour blends. Final viscosity range $(95.51-252.09$ RVU) was reported by [39] for wheat and walnut flour blends. Final viscosity is the most commonly used parameter for the quality of a starch based sample. High final viscosity gives an indication of the strength of the flour to form a viscous paste or firm gel after cooking and cooling, and also paste or gel resistance to shear force during stirring [27, 30]. This implies that the sample LAC with final viscosity of $171.17 \mathrm{RVU}$ will form a firm or viscous gel than all other samples.

The setback viscosity ranged between 31.50 and 67.42 RVU; sample LAC had the highest and sample BEL had the lowest values. There were no significant differences $(p \leq 0.05)$ among all samples investigated. The values of setback reported in this study are within the range 27 - 103 RVU documented by [30] for sorghum, mung beans and orange fleshed sweet potato flour blends. A range of $32.16-44.59$ RVU was reported by [27] for orange fleshed sweet potato and Bambara groundnut flour blends. A high setback viscosity is an index of the magnitude of swelling power of a flour sample. It is used as an index in measuring the tendency to undergo retrogradation of sample after heating and cooling. A high setback viscosity implies lower retrogradation of products during cooling. The values of setback viscosities documented in this study implies that samples LAC and BSA flour blends have lower tendency to retrograde than all other samples.

The pasting or peak times ranged between 5.27 and 5.40 minutes with samples LAC and CUO having the highest value while sample OPE having the least value. Samples $\mathrm{OPE}$ and $\mathrm{OAB}$ are significantly $(p \leq 0.05)$ lower than all other samples. The peak times recorded in this study are higher than the range 3.87 $4.60 \mathrm{~min}$. reported by [30] for sorghum, mung beans and orange fleshed sweet potato blends, and the range $2.93-5.46 \mathrm{~min}$. reported by [43] for selected varieties of sorghum and soybeans [27]. Reported a range between 4.37 and $5.13 \mathrm{~min}$ for Orange fleshed sweet potato and Bambara groundnut flour blends. Peak time is defined as the total time taken by the sample to attain its peak viscosity. It is the minimum time required to achieve the cooking [44].

The pasting temperature denotes the minimum temperature needed to cook a flour sample. It is the temperature at which the viscosity of the sample starts to rise. The combination of pasting temperature and pasting time is a measure of the energy cost of the operation. The pasting temperature of the blends ranged from 84.83 to $88.10^{\circ} \mathrm{C}$ with sample ITS having the minimum and sample $\mathrm{OAB}$ having the highest value. Significant differences $(\mathrm{p} \leq 0.05)$ exist among the samples. Samples CUO, OAK, OAB, and BUI are significantly higher than other samples. There were no significant differences $(\mathrm{p} \leq 0.05)$ among samples BSA, ITS, OTO, and OPE. The values of pasting temperatures obtained in this experiment are within the range $84.40-85.20^{\circ} \mathrm{C}$ reported by [26] for plantaincowpea based complementary food flours. The reported values of this study are higher than the range 80.21 $81.52^{\circ} \mathrm{C}$ recorded by [27] for orange fleshed sweet potato and Bambara groundnut flour blends and 80.70 84.12 reported by [30] for sorghum, mung bean and orange fleshed sweet potato blends. The attainment of the pasting temperature is necessary in ensuring 
swelling, gelatinization, and eventually gel formation during processing [39]. The results of pasting temperatures indicates that sample ITS will begin gelatinization at a lower temperature of about $84.83^{\circ} \mathrm{C}$ while sample $\mathrm{OAB}$ begins it gelatinization at a much higher temperature of about $88.10^{\circ} \mathrm{C}$. But sample OPE will cook faster while samples CUO and LAC will take more times to cook than other samples. It can be deduced from the foregoing that sample CUO will need more energy and samples ITS and OPE less energy to cook than all other sample.

\section{CONCLUSION}

This study has demonstrated that complementary foods can be produced from blends of fermented pearl millet, African yam bean and tiger nuts all cheap and readily available crops in most developing countries. This study revealed that all samples will make viscous or firm gels and good products most especially sample with $71.67 \%$ pearl millet, $16.67 \%$ African yam bean and $11.67 \%$ tiger nut flour; the sample with $70 \%$ pearl millet, $15 \%$ African yam bean and $15 \%$ tiger nut and the sample composed of $70 \%$ pearl millet, $20 \%$ African yam bean and $10 \%$ tiger nut.

\section{REFERENCES}

1. Michaelsen, K. F., Hoppe, C., Roos, N., Kaestel, P., Stougaard, M., Lauritzen, L., \& Friis, H. (2009). Choice of foods and ingredients for moderately malnourished children 6 months to 5 years of age. Food and nutrition bulletin, 30(3_suppl3), S343S404.

2. International Food Policy Research Institute. (2015). Global nutrition report 2015: Actions and accountability to advance nutrition and sustainable development. International Food Policy Research Institute.

3. Maeda, K., Ishida, Y., Nonogaki, T., \& Mori, N. (2020). Reference body mass index values and the prevalence of malnutrition according to the Global Leadership Initiative on Malnutrition criteria. Clinical nutrition, 39(1), 180-184.

4. Tufa, M. A., Urga, K., Weledesemayat, G. T., \& Mitiku, B. G. (2016). Development and nutritional assessment of complementary foods from fermented cereals and soybean. Journal of Food Science and Nutrition, 2(2), 1-8.

5. Abolaji, B. F., Edeke, E. J., \& Ajoke, S. M. (2019). Evaluation of chemical, functional and sensory properties of flour blends from sorghum, African yam bean and soybean for use as complementary feeding. Biotechnology, 4(3), 74-81.

6. Manning, K., Pelling, R., Higham, T., Schwenniger, J. L., \& Fuller, D. Q. (2011). 4500-Year old domesticated pearl millet (Pennisetum glaucum) from the Tilemsi Valley, Mali: new insights into an alternative cereal domestication pathway. Journal of Archaeological Science, 38(2), 312-322.

7. Davis, A. J., Dale, N. M., \& Ferreira, F. J. (2003). Pearl millet as an alternative feed ingredient in broiler diets. Journal of Applied Poultry Research,12(2), 137-144.

8. Gulia, S. K., Wilson, J. P., Carter, J., \& Singh, B. P. (2007). Progress in grain pearl millet research and market development. Issues in new crops and new uses, 196-203.

9. Kajuna, S. T. A. R. (2001). Millet: Post-Harvest Operations.(Edited by AGSI/FAO.), Sokoine University of Agriculture, Morogoro, Tanzania, 24 34.

10. Pascual, B., Maroto, J. V., López-Galarza, S., Sanbautista, A., \& Alagarda, J. (2000). Chufa (Cyperus esculentus L. var. sativus Boeck.): an unconventional crop. Studies related to applications and cultivation. Economic Botany, 54(4), 439-448.

11. Manek, R. V., Builders, P. F., Kolling, W. M., Emeje, M., \& Kunle, O. O. (2012). Physicochemical and binder properties of starch obtained from Cyperus esculentus. Aaps Pharmscitech, 13(2), 379-388.

12. Ezeh, O., Gordon, M. H., \& Niranjan, K. (2014). Tiger nut oil (Cyperus esculentus L.): A review of its composition and physico-chemical properties. European journal of lipid science and technology, 116(7), 783-794.

13. Oladele, A. K., \& Aina, J. O. (2007). Chemical composition and functional properties of flour produced from two varieties of tigernut (Cyperus esculentus). African Journal of Biotechnology, 6(21).

14. Roselló-Soto, E., Poojary, M. M., Barba, F. J., Koubaa, M., Lorenzo, J. M., Mañes, J., \& Moltó, J. C. (2018). Thermal and non-thermal preservation techniques of tiger nuts' beverage "horchata de chufa". Implications for food safety, nutritional and quality properties. Food Research International, 105, 945-951.

15. Klu, G.Y.P., Amoatey, H.M., Bansa, D., \& Kumaga, F.K. (2001). Cultivation and use of African yam bean (Sphenostylis stenocarpa) in the Volta region of Ghana. J. Food Technol. Afr. Innov. Instit. Commun, 6, $74-77$.

16. Moyib, O. K., Gbadegesin, M. A., Aina, O. O., \& Odunola, O. A. (2008). Genetic variation within a collection of Nigerian accessions of African yam bean (< I > Sphenostylis stenocarpa,/I $>$ ) revealed by RAPD primers. African Journal of Biotechnology, 7(12).

17. Raemaekers, R.H. (2001). Crop production in tropical Africa. Goeknit graphics nv.,Belgium, 372 - 374.

18. Uguru, M.I., \& S.O. Madukaife. (2001). Studies on the variability in agronomic and nutritive characteristics of African Yam bean (Sphenostylis sternocarpa Hochst en. A. Rich. Harms). Plant production and Research Journal, 6, 10 - 19

19. Amoatey, H.M., Klu, G.Y.P., Bansa, D., Kwnaga, F.k., Aboagye, L.M., Benett, S.O. and Gamedoagbao, D.K. (2000). African yam been (Sphenostylis sternocarpa) A neglected crop in Ghana. West African Journal of Applied Ecology, 1, 53 - 60.

20. Edem, D.O., Amygo, C.I., \& Eka, O.U. (1990). Chemical composition of yam beans (Sphenostylis sternocarpa). Tropical science, 30, 59 - 63

21. Nout, M.J.R., \& Rombouts, F.M. (1992). Fermentative preservation of plant foods. Journal of Applied Microbiology, 73, 136 - 147. 
22. Wang, S., \& Copeland, L. (2013). Molecular disassembly of starch granules during gelatinization and its effect on starch digestibility: a review. Food \& function, 4(11), 1564-1580.

23. Eke, S.O. (2018). Functional properties of African yam bean (Stenostylis stenocarpa) seed flour as affected by processing. Food Chemistry, 48, 337 340.

24. Onwuka, G.I. (2005). Food analysis and Instrumentation: Theory and practice, Naphtali Print, Lagos, Nigeria, 1 - 9.

25. AOAC. (2012). Association of Official Analytical Chemists (AOAC): Official methods of analysis, $25^{\text {th }}$ Edition, Washington D.C.

26. Olapade, A.A; Babalola, K.A., \& Aworh, O.C. (2015). Evaluation of plantain and cowpea blends for complementary foods. Journal of International Scietific Publications, 3, 274 - 288.

27. Obomeghei, A.A., \& Ebabhamiegbebho, P.A. (2020). Proximate composition, functional and pasting properties of orange fleshed sweet potato and red Bambara groundnut flour blends for snacks formulation. Asian Food Science Journal, 17 (1), 38 47.

28. Adesanmi, A.R; Malomo, S.A. and Fagbemi, T.N. (2020). Nutritional quality of formulated complementary diet from defatted almond seed, yellow maize and quality protein maize flours. Food Production, Processing and Nutrition, 2, 23 - 34.

29. Akinbode, B.A., \& Origbemisoye, B.A. (2020). Quality characterization of complementary food produced from orange fleshed sweet potato supplemented with cowpea and groundnut flour. Journal of Food Stability, 3(2), 90 - 104.

30. Olaleye, H. T., Oresanya, T. O., \& Temituro, E. O. (2020). Quality Assessment of Weaning Food from Blends of Sorghum, Mung Beans and Orange Fleshed Sweet Potato Blends. European Journal of Nutrition \& Food Safety, 42-52.

31. Houssou, P., \& Ayernor, G. S. (2002). Appropriate processing and food functional properties of maize flour. African Journal of Science and Technology, 3(1).

32. Sanoussi, A. F., Dansi, A., Bokossa-Yaou, I., Dansi, M., \& Egounlety, M. (2013). batatas) based infant flours fortified with soybeanand sorghum flours. Int. J. Curr. Microbiol. App. Sci, 2(7), 22-34.

33. Obomeghei, A. A., Olapade, A. A., \& Akinoso, R. (2020). Evaluation of the chemical composition, functional and pasting properties of four varieties of Nigerian sweet potato [Ipomoea batatas L.(Lam.)] flour. African Journal of Food, Agriculture, Nutrition and Development, 20(3), 15764-15778.
34. Wootton, M., \& Bamunuarachchi, A. (1978). Water binding capacity of commercial produced native and modified starches. Starch-Stärke, 30(9), 306-309.

35. Ijarotimi, O. S., \& Keshinro, O. O. (2021). Formulation and nutritional quality of infant formula produced from germinated popcorn, Bambara groundnut and African locust bean flour. Journal of Microbiology, Biotechnology and Food Sciences, 2021, 1358-1388.

36. Tortoe, C., Akonor, P.Y., Koch, K., Menxel, C., \& Adofo, K. (2017). Physicochemical and functional properties of flour from twelve varieties of Ghanian sweet potatoes. Int. Food Res. Journal, 24(6), 2549 2556.

37. Ijarotimi, O.S., \& Keshinro, O.O. (2012). Formulation and nutritional quality ofinfant formula produced from germinated popcorn, bambara groundnut and African locust bean flour. Journal of Microbiology, Biotechnology and Food Sciences, 1, 1358 - 1388.

38. Bankole, Y. O., Tanimola, A. O., Odunukan, R. O., \& Samuel, D. O. (2013). Functional and nutritional characteristics of cassava flour (lafun) fortified with soybeans. Journal of Educational and Social Research, 3(8), 163-163.

39. Offia-Olua, B. I. (2014). Chemical, functional and pasting properties of wheat (Triticumspp)-walnut (Juglansregia) flour. Food and Nutrition Sciences, 2014.

40. Ojo, M. O., Ariahu, C. C., \& Chinma, E. C. (2017). Proximate, functional and pasting properties of cassava starch and mushroom (Pleurotus pulmonarius) flour blends. American Journal of Food Science and Technology, 5(1), 11-18.

41. Iwe, M. O., Onyeukwu, U., \& Agiriga, A. N. (2016). Proximate, functional and pasting properties of FARO 44 rice, African yam bean and brown cowpea seeds composite flour. Cogent Food \& Agriculture, 2(1), 1142409.

42. Beta, T., \& Corke Noodle, H. (2002). Quality as related to sorghum starch properties. Cereal Chemistry, 78, $417-420$.

43. Usman, M. A., Bolade, M. K., \& James, S. (2016). Functional properties of weaning food blends from selected sorghum (Sorghum bicolor (L.) Moench) varieties and soybean (Glycine max). African Journal of Food Science, 10(8), 112-121.

44. Adewale, K.O., \& Lawal. O.S. (2004). Comparative study of the functional properties of Bambara groundnut (Voandzeia subterranean), jack bean (Canavalia ensiformis) and mucuna bean (mucuna pruriens) flours. Food Research International, 37, 355 -365 .

Cite This Article: Obomeghei AA et al (2021). Comparison of the Functional and Pasting Characteristics of Millet (Pennisetum Glaucum), African Yam Bean (Sphenostylis Stenocarpa Hoechst Ex. A. Rich) and Tiger Nut (Cyperus Esculentus) Flour Blends for Complementary Food Production. EAS J Nutr Food Sci, 3(2), 42-49. 